\title{
TUFFACEOUS CONGLOMERATES: SYN-ERUPTIVE RESEDIMENTED DEBRIS FLOW AND HYPERCONCENTRATED FLOW DEPOSITS FROM THE "RHYODACITIC FORMATION", GUTÂI MTS, EASTERN CARPATHIANS
}

\begin{abstract}
ALEXANDRINA FULOP ${ }^{1}$
ABSTRACT. The first volcanic products from Gutâi Mts, Eastern Carpathians belong to the "Rhyodacitic Formation". The physical constituents of this formation are as follows: pyroclastic deposits (ignimbrites and fall tuffs), syn-eruptive resedimented volcaniclastic deposits, volcanogenic and non-volcanogenic sedimentary deposits.

The tuffaceous conglomerates belong to the syn-eruptive resedimented volcaniclastics and represent the coarsest deposits. They outcrop in Băița area, west from Baia-Mare, being underlain by Lower Badenian $(15.4 \pm 0.6 \mathrm{Ma})$ ignimbrites and overlain by Lower Sarmatian claystones.

The main components of the conglomerates are boulders and cobbles of sedimentary and metamorphic rocks in a tuffaceous matrix. Scarse blocks eroded from the lower ignimbrite unit are present. In the frame of the study of the "Rhyodacitic Formation", the conglomerates have been investigated using facies analysis. The facies model concludes that the studied deposits have been emplaced from debris flows and hyperconcentrated flows. They derived from subaerial channelized ignimbrite flows, which underwent strong flow separation while jumping in submarine basin and settling in deep water, below wave base. Such conditions, above the lower subaerial ignimbrite unit, were determined by the subsidence of Săsar-Dealu Crucii compartment, contemporaneously developed with the conglomerates emplacement.
\end{abstract}

Key words: tuffaceous conglomerates, syn-erupted resedimented, facies analysis, ignimbrite, flow separation, debris flow, hyperconcentrated flow, submarine basin, wave base, subsidence.

\section{INTRODUCTION}

Gutâi Mountains are part of the Carpathian volcanic arc, edified during complex subduction processes. The "Rhyodacitic Formation", built up above the Paleogene flysch, marks the beginning of the volcanic activity in this area. It started in the Lower Badenian with acidic ignimbrites, dated as $15.4 \pm 0.6 \mathrm{Ma}$. In Lower Sarmatian, an andesitic volcanic activity had started (13.1 $\pm 0.9 \mathrm{Ma})$ and continued up to Upper Pannonian $(7 \pm 0.4 \mathrm{Ma})$, according to Pecskay et al

\footnotetext{
${ }^{1}$ North University of Baia Mare, Faculty of Mining and Metallurgy, 62/A, V. Babeş street, 4800
} Baia Mare 
(1994, 1995). A long suite of andesitic rocks built up impressive volcanic structures (stratovolcanoes, effusive cones) or filled volcano-tectonic depressions, interlayering with sedimentary deposits. Acidic extrusions and shallow depth intrusions pierced the complex structures.

This paper approaches the problem of some deposits of conglomerates, as components of the "Rhyodacitic Formation". The "Rhyodacitic Formation" is composed of ignimbrites and associated fall deposits, syn-erupted resedimented mass flow volcaniclastics and volcanogenic and non-volcanogenic sedimentary deposits. This terminology is in accordance with McPhie et al (1993). Syneruptive resedimented reffers to two types of volcaniclastics: those resedimented from subaerial ignimbrite flows in deep water, under the initial eruptive momentum and those rapidly resedimented from shallow water to deep water, by gravitational processes, after the eruptive momentum had ceased. In volcanic fields, the submarine basin is divided into shallow water or above wave base and deep water or below wave base environments (McPhie et al 1993). The wave base corresponds to the level of storm waves: above it, the sea bed is affected by surface waves; below it, the sea bed is not affected by surface waves (Nichols 1999), preserving thus its deposits.

The conglomerates have been studied using the facies analysis, in the frame of the study of the "Rhyodacitic Formation". The facies analysis uses the descriptive facies (lithology, sedimentary structures, geometry) in order to interpret deposits in terms of transport and emplacement mechanisms. The final facies model links genesis, transport and settling mechanisms with the inffered environment. The identified connection between the conglomerates and ignimbrite flows allowed the approach of syn-eruptive resedimented volcaniclastics and their involved processes.

The study of the conglomerates is based on the outcrops found in Băița area, southern part of Gutâi Mountains (Fig. 1). The conglomerates are erosionally under-lain by subaerially emplaced welded ignimbrites and continuously overlain by interlayers of claystones and tuffaceous sandstones of the same formation. They have been described by the Prospecting team of IPEG Maramureş (Morar et al 1991). Although associated to volcaniclastic deposits, nobody has noticed the volcaniclastic character of the conglomerates, the pumiceous composition of the matrix.

FACIES ANALYSIS OF THE TUFFACEOUS CONGLOMERATES

The tuffaceous conglomerates are outcropping on Ulmoasa valley and Limpedea valley, including two of Limpedea valley tributaries. The descriptive facies have been represented on three lithological columns, carried out in the most important outcrops (Fig. 3, 4, 5). Fig. 2 presents the legend used for the lithological columns. 
TUFFACEOUS CONGLOMERATES: SYN-ERUPTIVE RESEDIMENTED DEBRIS FLOW

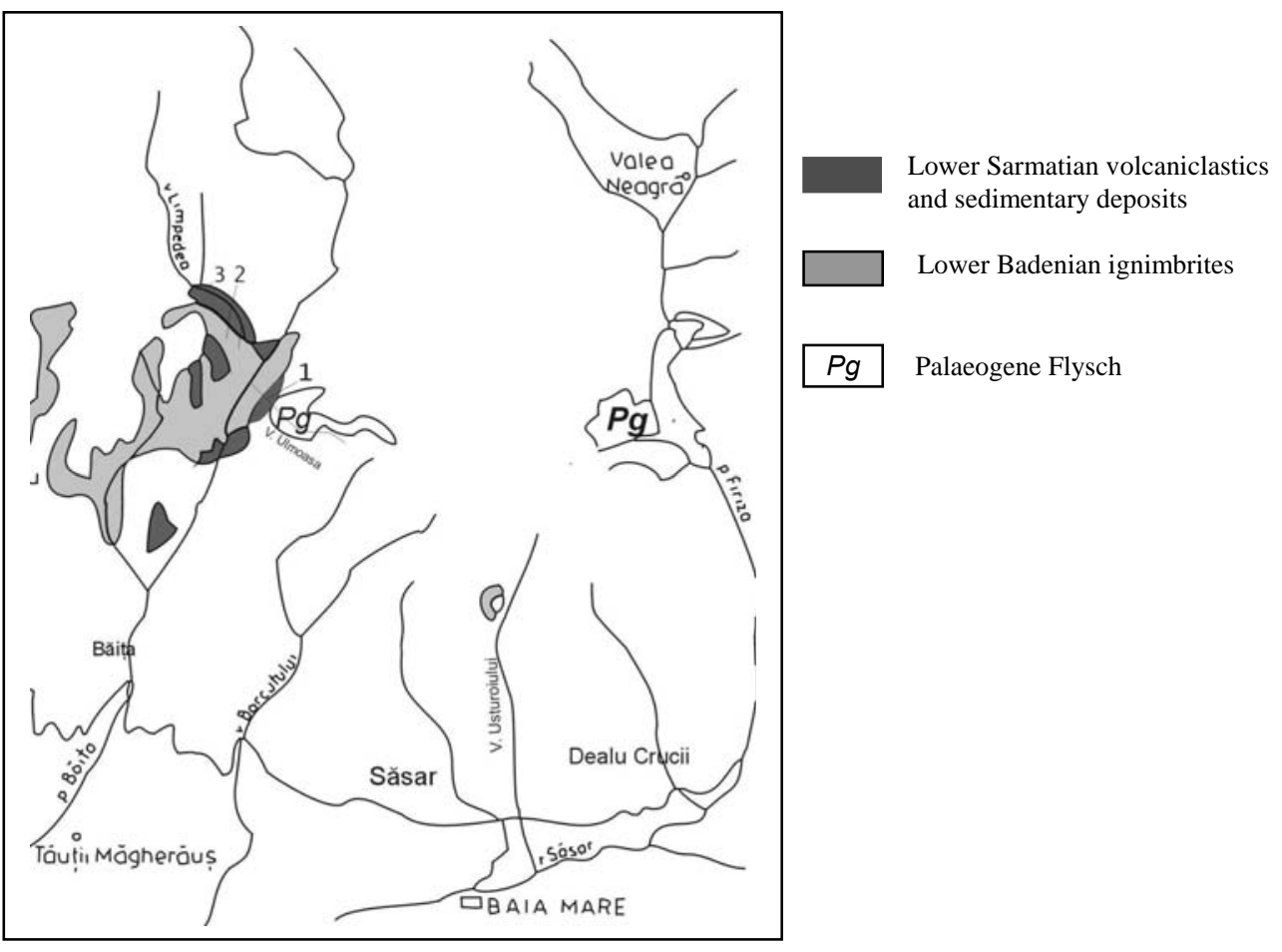

Fig. 1. Locations of the main outcrops of tuffaceous conglomerates in Băița area LEGEND

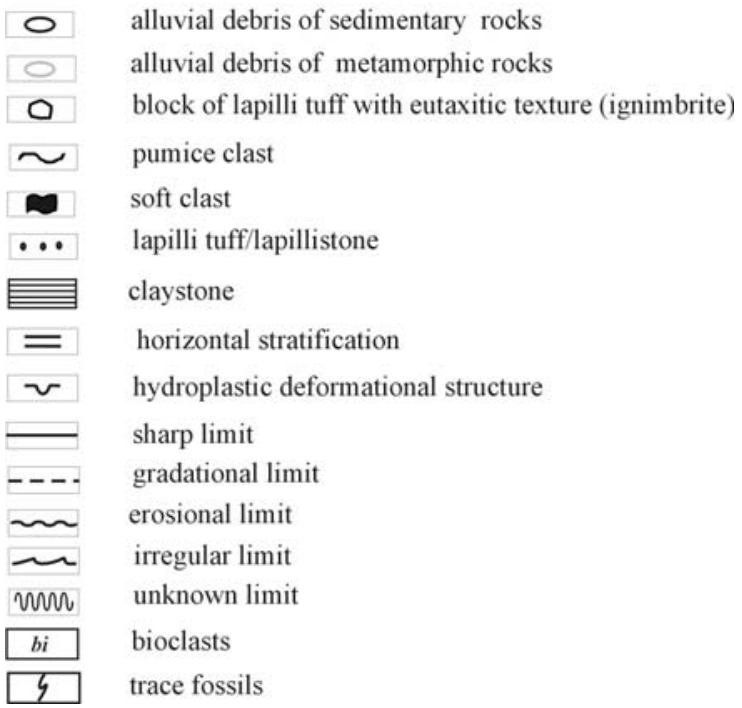

Fig. 2. 


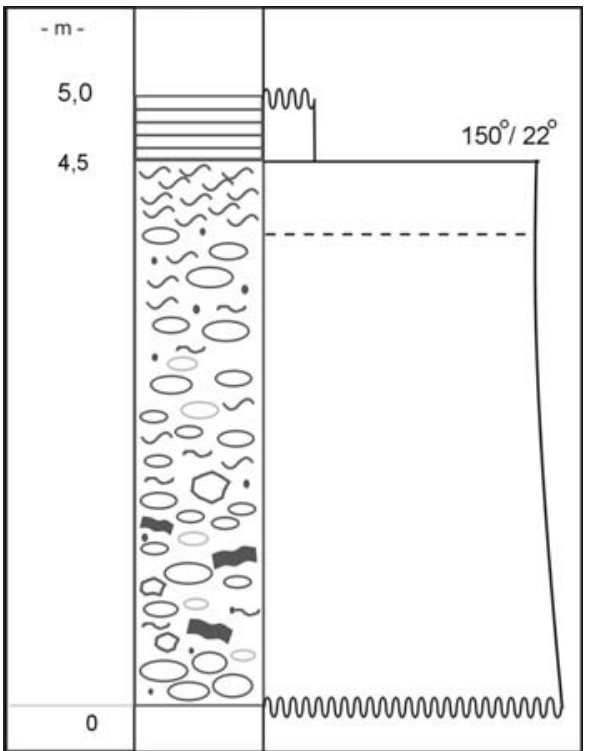

Fig. 3. Lithological column of outcrop (1) from Ulmoasa valley

The outcrop (1) from Ulmoasa valley (Fig. 3) shows four meters thick polymict conglomerate with tuffaceous matrix (Plate 1, Fig. 3), gradually overlain by a half meter thick pumice rich unit ( Plate 1, Fig. 1).

The physical constituents of the conglomerates are the clasts and the matrix. The clasts are represented by sedimentary rocks: sandstones, siltstones and claystones; metamorphic rocks: quartzites, quartz schists; igneous rocks: lapilli tuffs with eutaxitic texture (ignimbrites). The sedimentary clasts, representing fragments of the Paleogene flysch, are predominant. The ignimbrite clasts are provided by the underlain unit. The metamorphic rocks from the crystalline basement are very rare. The matrix is composed of juvenile pyroclasts: pumice clasts completely pseudomorphosed by phyllosilicates; quartz; plagioclase pseudomorphosed by triclinic adularia \pm phyllosilicates \pm carbonates; argillised glass shards mixed with intra-basinal clays.

The upper pumice rich layer is composed of pumice clasts and a small amount of ash matrix. They show the same pseudomorphosis with phyllosilicates, as within the lower conglomerate unit.

The juvenile pyroclasts suggest magmatic explosions.

The components of the conglomerates cover a wide range of grainsizes, from the predominant (maximum $75 \mathrm{~cm}$ ) boulders and cobbles and the subordinate pebbles and granules, to the fine sandy matrix, composed of pumice lapilli and fine volcanic ash mixed with clays. These 
grainsizes correspond to a very poorly sorted deposit, a matrix-supported conglomerate, a paraconglomerate or a sandy conglomerate with lapilli tuff matrix. This texture is typical for the mass-flow deposits.

The grainsize of the pumice clasts from the pumice-rich layer corresponds to lapilli. They are associated with o small amount of ash, forming a pumice lapillistone.

The shapes of the clasts were defined by measuring their axes and approaching them to spheres, discs or rods. According to Table 1, b/a< 0.67 and $c / b<0.67$, suggesting that most of the clasts are bladed (Anastasiu and Jipa 1983).

\begin{tabular}{|c|c|c|c|c|c|}
\hline Outcrop1 & $a$ & $b$ & $c$ & $b / a$ & $c / b$ \\
\hline 1 & 30 & 15 & 7 & 0,42 & 0,46 \\
\hline 2 & 25 & 10 & 6 & 0,4 & 0,6 \\
\hline 3 & 23 & 10 & 6 & 0,43 & 0,6 \\
\hline 4 & 15 & 8 & 5 & 0,53 & 0,62 \\
\hline 5 & 4 & 3 & 1 & 0,75 & 0,33 \\
\hline
\end{tabular}

$a$ represents the longest axis (length), $b$ represents the intermediate one (width) and $c$ represents the shortest axis (thickness) of the clasts. This is available only for the sedimentary and metamorphic clasts which shapes suggest alluvial debris. The fragments of ignimbrites are large broken blocks with subangular form; they do not suggest reworking processes. Some of the claystone clasts have irregular shapes, with marginal mixing with the volcaniclastic matrix. They are soft clasts, suggesting a plastic behaviour when they have been incorporated by the mass flows.

The juvenile components of the tuffaceous matrix and pumice lapillistone show the following shapes: the pumice clasts are flattened, undulated and deformed; the quartz phenocrysts are subrounded or subangular, fragmented, with a jig-saw fit or puzzle texture; the plagioclase phenocrysts show the typical subhedral prismatic shape, rarely fragmented.

The shapes of the pyroclasts are indicating both the primary magmatic features of the intratelluric phenocrysts and the explosive fragmentation. The jig-saw fit or puzzle texture is typical for the subaqueous fragmentation (Fisher 1984). The pumice flattening and deformation correspond to diagenesis.

A review of the lithofacial interpretation suggests a mass-flow deposit composed of alluvial debris and a tuffaceous matrix, reflecting both the primary explosive and the secondary subaqueous fragmentation. It is gradually capped by a pumice-rich layer, both of them being diagenetically compacted. The primary pyroclastic character of the flow is obvious. On its pathway, it interacted with water-saturated claystones and incorporated the soft clasts together with the alluvial debris. 
The sedimentary structures show a massive, chaotic facies. The clasts show a crude normal coarse-tail grading; some of the larger clasts appear at the upper levels of the deposit and most of them are aligned, suggesting a flow lineation. The soft clasts are concentrated in the lower half of the deposit and a clast-rich, matrix-poor layer seems to determine the basal part of the conglomerate. The associated pumice concentration zone shows a crude layering due to the aligned pumice clasts.

The identified facial characteristics correspond to debris flows, highly concentrated plastic flows, with a cohesive matrix. This sandy matrix represents the clasts support during the laminar flow. The large clasts at high levels suggest an increased competence of the matrix, due to the mixture of the clays, volcanic clasts and water (Fisher 1994). However, the concentration of the largest clasts in the basal layer, where traction mechanism may be dominant, expresses the limited capacity of the largest clasts to be supported by the matrix. The downward concentration of the larger clasts due to gravitational segregation is typical for the laminar, viscous flows. The aligned flattened clasts correspond to the development of shear stress during the laminar flow. Debris flows are sometimes erosive, as in this case, when soft clasts and ignimbrite blocks are abundant, suggesting they have been broken from the underlaying or marginal deposits.

The associated pumice-rich layer suggests the upper part of this volcaniclastic debris flow which has determined the floating of the larger pumice clasts and their upper concentration. The planar lamination might also have been determined by the settling from suspension of pumice clasts and ash, previously separated from the mass flow.

The debris flow deposits have been emplaced by en-masse "freezing", more probable than by progressive aggradation (Branney and Kokelaar 1992), because of the massive, structureless character of the deposits.

The geometry of the tuffaceous conglomerates, the limited lateral extent, as well as the debris flow character, are compatible with an alluvial channel filling; the volcaniclastic flows eroded the bottom of the pathway and the overbank and incorporated the alluvial clasts and the soft clasts, being emplaced en masse.

The outcrops identified on two of the Limpedea valley right side tributaries show coarse tuffaceous conglomerates (Plate 1, Fig. 4), gradually overlain by a pumice concentration zone (Plate 1, Fig. 2), with a total thickness of about $28 \mathrm{~m}$. The pumice concentration zone has also been identified on Limpedea valley, where it is sharply covered by two other similar but thinner $(6 \mathrm{~m}$ and $2.5 \mathrm{~m}$, respectively) and finer units. Above them, a layer of $0.5 \mathrm{~m}$ of claystones separates the sequence from the third, $1.5 \mathrm{~m}$ thick, unit. The lithological column represents the synthetical column of the whole succession of outcrops (2), identified on the two tributaries and 
on Limpedea valley (Fig. 4). The three units sequence has been defined as a fining and thinning upwards sequence, but it has not environmental connotatios. Each unit, sharply delinated above and below, shows the same composition and almost the same internal organization.

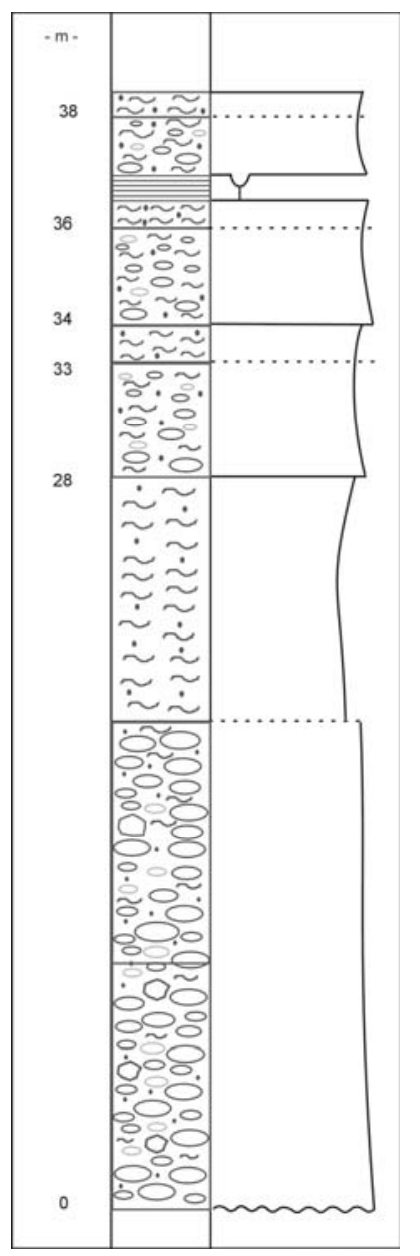

Fig. 4. Synthetic lithological column of the succession of outcrops (2) from Limpedea valley and its tributaries

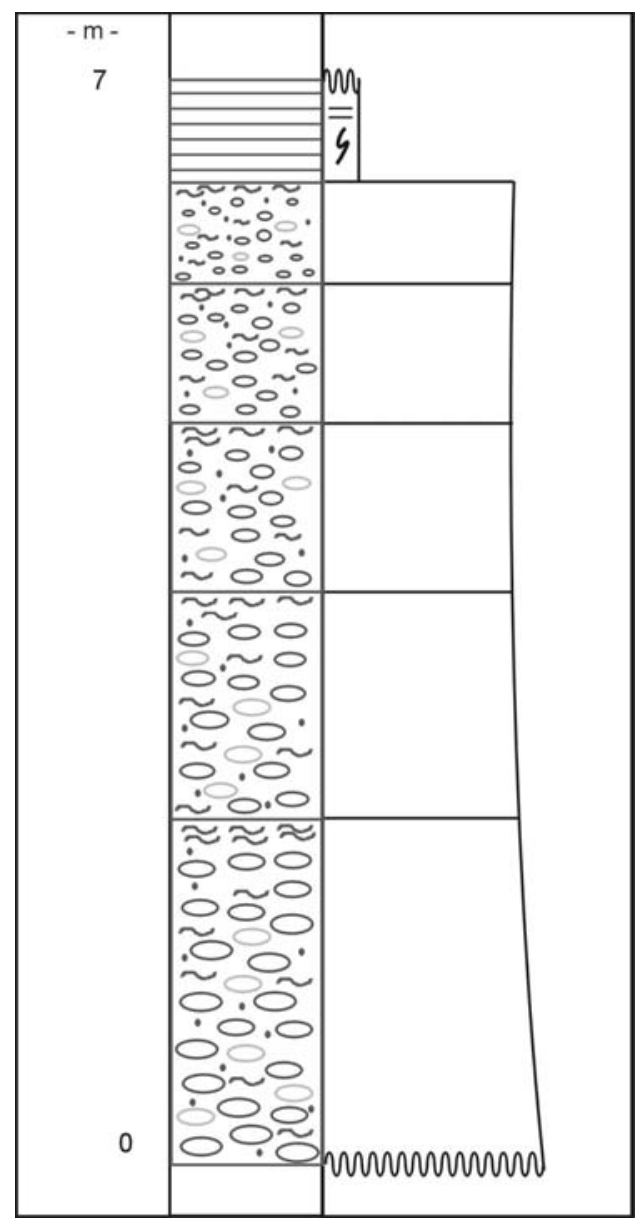

Fig. 5. Lithological column of outcrop (3) from Limpedea valley

The coarse conglomerate lower part is composed of clasts and a very small amount of tuffaceous matrix concentrated upwards, gradually passing into the pumice-rich layer. 
The clasts are represented by sedimentary rocks: sandstones, argillic siltstones and claystones; metamorphic rocks: quartzites; igneous rocks: lapilli tuffs with eutaxitic texture (ignimbrites). Their origin suggests the Paleogene flysch, the crystalline basement and the underlain ignimbrite unit.

The matrix is composed of: completely argillized pumice clasts; quartz; adularised plagioclase; argillised glass shards.

The pumice concentration zone or the pumice-rich layer is composed of argillized pumice clasts and a small amount of argillized ash.

The volcanic clasts of the matrix and pumice-rich layer are indicating the pyroclastic origin, particularily the ignimbrite juvenile components.

The clasts are very different from the grainsize point of view: boulders are predominant, associated with cobbles; the grainsize of the matrix corresponds to lapilli tuffs. The lower part of the conglomerate suggests a clast-supported rock, an orthoconglomerate which passes vertically into a matrix-supported rock, a tuffaceous paraconglomerate. The texture suggests a mass flow, because of the matrix-supported character. The basal moderate sorting passes vertically into poor sorting. The upper pumice rich layer concentrates the largest pumice lapilli in a pumice lapillistone. The shapes of the clasts are determined by the ratios of the measured axes, as presented in the next table:

\begin{tabular}{|c|c|c|c|c|c|}
\hline Outcrop 2 & $a$ & $b$ & $c$ & $b / a$ & $c / b$ \\
\hline 1 & 18 & 6,5 & 4 & 0,36 & 0,61 \\
\hline 2 & 11 & 6,5 & 2 & 0,59 & 0,30 \\
\hline 3 & 5 & 4 & 1,5 & 0,8 & 0,37 \\
\hline 4 & 10 & 8 & 3,5 & 0,8 & 0,43 \\
\hline 5 & 1,8 & 1,3 & 0,6 & 0,72 & 0,46 \\
\hline
\end{tabular}

Table 2.

Most of the shapes suggest discoid or oblate forms (b/a> 0.67 and $c / b<0.67)$ but bladed forms $(b / a<0.67$ and $c / b<0.67)$ are also frequent (Anastasiu and Jipa 1983).

The pyroclastic components of the matrix have the following shapes: deformed, flattened, undulated pumice clasts; subangular, fragmented quartz phenocrysts; subhedral, prismatic plagioclase, rarely subangular, fragmented.

The pumice lapillistone contains flattened, undulated pumice clasts, as does the matrix of the conglomerate.

The large clasts represent alluvial debris. The volcaniclastic components, the pyroclasts, are products of magmatic explosive eruptions which preserve their original shapes (except pumice, deformed due to diagenesis).

The lithofacies, emphasized by the lithological column (Fig. 4), indicates a thick sequence of ortho- to paraconglomerate with a tuffaceous matrix, passing into a pumice lapillistone. It corresponds to a volcaniclastic mass flow, derived from an ignimbrite flow, which picked up the alluvial debris on its pathway. The two upper units have similar lithofacies. 
The study of the sedimentary stuctures shows massive, structureless deposits, with a very small amount of matrix, in accordance with a very concentrated mass flow. The basal clast- supported part seems to be emplaced from a hyperconcentrated flow, upward passing into a viscous, plastic laminar flow, entrained by both the cohesive matrix and the collisional interaction of the particles. The very dense flow inhibited the traction, but it is possible for the clasts close to the bottom, to be transported by traction processes.

The associated upper pumice concentration zone shows a crude layering compatible with the laminar flow. It is composed of the largest pumice clasts concentrated upwards due to the floating capacity of pumice. The possible deposition of the pumice clasts and ash from the suspension associated to the mass-flow cannot be ignored.

Therefore, the mass flows may be defined as transitions from debris flows to hyperconcentrated flows, emplaced by either en masse freezing or progressive aggradation. The other two units have the same internal organization, showing a debris flow character.

The fining and thinning upwards sequence, composed of units of debris flow and hyperconcentrated flow deposits, is the resulted stratified deposit, emplaced by progressive aggradation from a single thick flow unit. The last, thinnest unit, separated from the sequence by a layer of claystones (Fig. 4), presents hydroplastic deformational structures. Its emplacement was delayed from the emplacement of the parental flow, suggesting its later resedimentation, by gravitational processes.

The geometry of the sequence suggests the channel filling.

Conclusions focus on debris flows and hyperconcentrated flows of volcaniclastic character, derived from channelized subaerial ignimbrite flows, emplaced by progressive aggradation processes.

The last outcrop, (3), identified uphill on Limpedea valley, shows a fining and thinning upwards sequence of conglomerate units with tuffaceous matrix, separated by gradational limits. Only the upper 5 units are visible, having the following thicknesses: $2.2 \mathrm{~m}, 2.0 \mathrm{~m}, 1.8 \mathrm{~m}, 1.2 \mathrm{~m}$ and $0.75 \mathrm{~m}$. Each unit is capped by a few centimeters thick pumice-rich layer (Fig. 5).

The clasts (Plate 2, Fig. 1,2) are represented by sedimentary rocks: sandstones; metamorphic rocks: quartzites, quartz schists; igneous rocks: lapilli tuffs with eutaxitic texture (ignimbrites).

The matrix is composed of: argillized pumice clasts; quartz; plagioclase pseudomorphosed by adularia; biotite pseudomorphosed by hydromicas, devitrified and argillized ash and diagenetic carbonates (Plate 3, Fig. 3, 4).

The upper pumice rich layers contain argillized pumice clasts and a small amount of argillized ash. 
As in the previous outcrops, the clasts are provided mainly by the Paleogene flysch and subordinated by the crystalline basement. The matrix and the pumice rich layer suggests the pyroclastic origin. The secondary minerals indicate both dia-genetical and hydrothermal processes.

The clasts grainsize corresponds to cobbles and subordinate to pebbles. The very small amount of matrix indicates a lapilli tuff and the pumice rich layer corresponds to a pumice lapillistone. The rocks are clastsupported or orthoconglomerates and show a moderate sorting.

The shape of the clasts suggests alluvial debris. The morphology of the pyroclasts within the matrix reflects both the magmatic fragmentation and the jig- saw fit texture, typical for the subaqueous fragmentation (Fisher 1984).

The lithofacies indicates orthoconglomerates with tuffaceous matrix and relates their formation to pyroclastic, ignimbrite explosions and channelized flows, respectively.

The sedimentary structures are characterized by two elements: the horizontal stratification which separates the units and the grading, expressed both at the level of the units and at the level of the sequence.

Each unit shows a weak normal coarse-tail grading of the clasts and a weak reverse coarse-tail grading of the pumice clasts, which are concentrated at the upper part of the unit, in a 1-2 cm thick layer. The sequence, as a whole, presents only the normal coarse-tail grading of the clasts.

The sedimentary structures correspond to deposits emplaced from hyperconcentrated flows. The high concentration allows only a weak grading. The grading of the pumice clasts at the top of each unit is based on their capacity of floating but the very thin layers suggest that very few pumice clasts move upwards, some of them being trapped among the dense clasts or lost in the surrounding fluid.

The hyperconcentrated flows derived from the original ignimbrite flows, strongly enriched in alluvial debris. The fining and thinning upwards sequence suggests the pulses of the hyperconcentrated flow and the emplacement by progressive aggradation

The geometry indicates the typical channel filling, with a large amount of alluvial debris and limited lateral extent.

\section{FACIES MODEL}

A review of the interpretative facies shows:

- genetical relationships between conglomerates and magmatic explosions, ignimbrite flows respectively;

- subaqueous, in situ fragmentation;

- strong flow separation processes involving water; 
- debris flow and hyperconcentrated flow mechanisms;

- en-masse "freezing" and/ or progressive aggradation emplacement, associated with settling from suspension;

- channel filling geometry;

The facial characteristics of the outcrops suggests the flow transformation (Fisher 1983) of the subaerial ignimbrite flows into subaqueous debris flows and hyperconcentrated flows and their emplacement in subaqueous setting, by en-masse "freezing" and/ or progressive aggradation processes. The subaqueous deposition is suggested by the strong flow separation, loose of most of the ash and pumice clasts, in situ fragmentation; it is enhanced by the association with the overlain claystones, settled from suspension, containing Lower Sarmatian marine fauna.

The impact of the subaqueous environment on the subaerial pyroclastic flows, particularly on the ignimbrite flows, has been studied by Cas and Wright (1991) and Mandeville et al (1996). They describe the entrance of the pyroclastic flows in submarine basins. At gentle slopes and low speeds, the flow preserves its entity and hot state deposition. On the contrary, at steep slopes and high speeds, the jump of the flow determins a strong hydraulic sorting or the fluidisation grading. Most of the original ash and pumice clasts are separated from the parental flows, first of all in the associated ash cloud, into the atmosphere and secondly, into the basin (Fig. 6). Some large pumice clasts are trapped by the flow and concentrated in an upper layer due to their buoyancy; others are gradationally overlying the coeval mass- flow, being emplaced from suspension, associated with a small amount of ash.

These processes were involved in the formation of the studied conglomerates. The strong flow separation determined the deposition of the dense underflow, more or less capped by the pumice-rich layer settled from flotation or suspension, because of the cease of the initial eruptive momentum. The emplacement on the sea bottom, in quiet, below wave base submarine environment, explains their preservation (McPhie et al 1993).

The fossil fauna, emphasized by the claystones from Limpedea valley, is composed of: Cardium gleichenbergense Papp., Cardium (Cuastoderma) lithpodolicum Dubois, Ervilia dissita dissita (Eichw.), Ervilia dissita podolica (Eichw.), Modiola sp. (according to Rădulescu et al 1970). It indicates the Lower Sarmatian. On the same valley, the identified trace fossils suggest Palaeophycus; it belongs to an assemblage which characterizes coastal environments, restricting the depth to an offshore shelf. Both marine and brackish water conditions are also suggested (Pemberton et al in Walker and James 1992). 


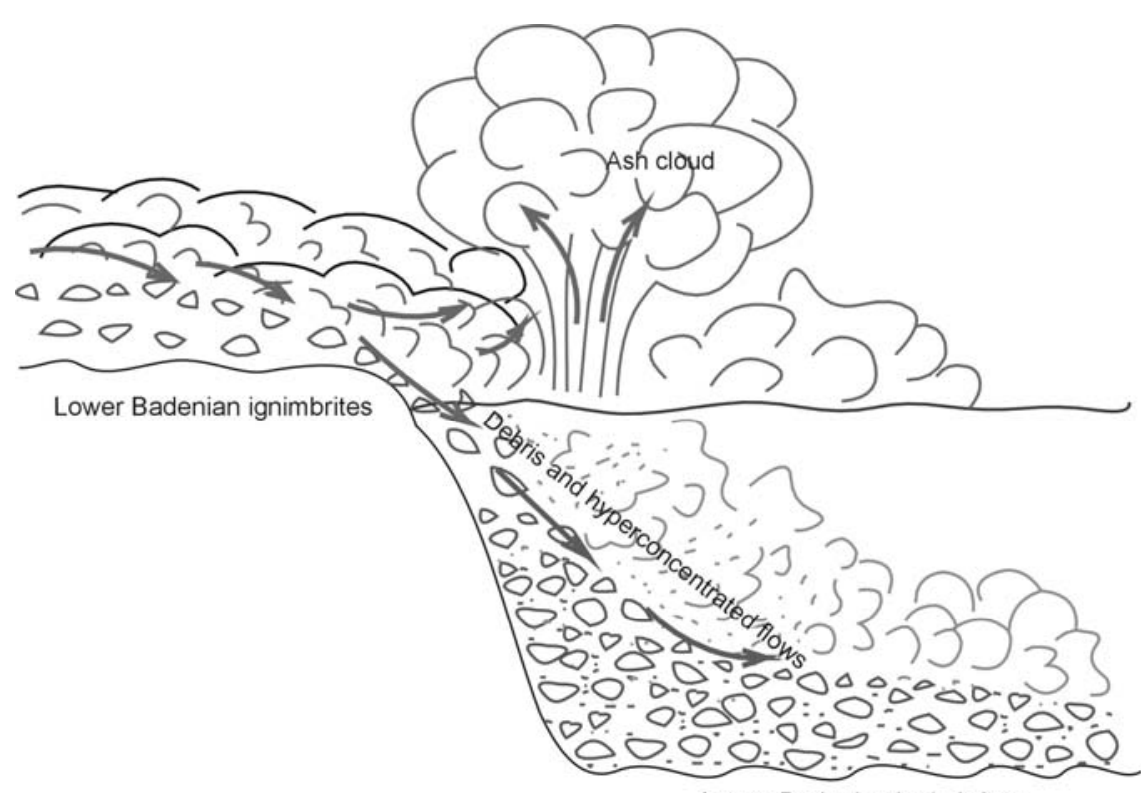

Lower Badenian ignimbrites

Fig. 6. Facies model of the tuffaceous conglomerates

The problem that remains to be solved is to explain why subaqueously, deep water emplaced debris flows and hyperconcentrated flows, lay over subaerially emplaced and eroded ignimbrites, without any interbedded deepening sedimentary sequence. The tectonic frame of SăsarDealu Crucii area, eastern from Băița, is able to explain this relationship. This compartment represents a collapsed area. The lower ignimbrite unit is sunken eastern from Limpedea valley, with about $150 \mathrm{~m}$ relative to the western part. This subsidence of local character is associated with the extent of submarine conditions from the southern Baia-Mare basin and with the emplacement of the studied mass flows (Fig. 6). It also explains the abnormal lateral contact between the conglomerates and the underlain ignimbrites, imediately western from Limpedea valley (Fig. 1). It is supposed that this valley represents the western limit of the subsided area.

The subsidence of Săsar-Dealu Crucii compartment is thus contemporaneous with the debris flows and hyperconcentrated flows emplacement, in Lower Sarmatian. Both the source and the pathways of the supposed ignimbrite flows are unknown yet and beyond the aim of this paper.

The deep water sedimentation has continued after the conglomerates emplacement, with claystones interlayered with other volcaniclastics, involving the resedimentation of the same original pyroclastic debris, by gravitational processes. 


\section{CONCLUSIONS}

The tuffaceous conglomerates from Băița area, southern part of Gutâi Mts, are emplaced from the underflow of syn-eruptive resedimented debris flows and hyperconcentrated flows, in submarine deep water, below wave base environment. The depth corresponds to an offshore shelf and both marine and brackish waters are suggested. The age, based on the faunal contents, is considered to be Lower Sarmatian.

The syn-eruptive resedimented debris flows and hyperconcentrated flows derived from subaerial pyroclastic flows of ignimbrite origin, related to magmatic explosions of an unknown source. The ignimbrite flows were channelized, picking up most of the existed alluvial debris. They had jumped into a submarine basin, undergoing a strong flow separation into a dense underflow which concentrated the coarse alluvial debris and an upper, more or less preserved pumice-rich layer. Most of the volcanic ash and pumice clasts were lost in the atmosphere and the surrounding basin. The conglomerates were emplaced by en masse "freezing" and/or progressive aggradation, when the eruptive momentum had ceased.

The submarine deep water conditions were determined by the subsidence of the Săsar-Dealu Crucii compartment, contemporaneously developed with the mass flows settling. Tens of meters of deep water sedimentary deposits and interlayered volcaniclastics, emplaced above the tuffaceous conglomerates, suggest the maintenance of these conditions due to the continued subsidence of the area.

\section{REFERENCES}

1. Anastasiu N., Jipa D., 1983: Texturi şi structuri sedimentare, Bucureşti, Ed. Tehnică.

2. Branney J., M., Kokelaar P., 1992 - A reappraisal of ignimbrite emplacement: progressive aggradation and changes from particulate to non-particulate flow during emplacement of high-grade ignimbrite; Bull. Volcanol., vol 54, pp. 514.

3. Cas R.A.F., Wright J., V., 1991: Subaqueous pyroclastic flows and ignimbrites: an assesment; Bull. Volcanol., vol 53, pp 357

4. Fisher R.V., 1983: Flow transformations in sediment gravity flows: Geology VII, p. 273-274.

5. Fisher R.V., 1984: Submarine volcaniclastic rocks in: Marginal basin geology,volcanic and associated sedimentary and tectonic processes in modern and ancient marginal basins, Kokelaar B.P and Howells M.F. (eds), Blackwell Scientific Publications 


\section{ALEXANDRINA FULOP}

6. Fisher R. V., Schmincke H. U., 1994: Volcanoclastic sediment transport and deposition; reprinted from Sediment Transport and Depositional Processes edited by Kenneth Pye, Blackwell Scientific Publications.

7. Mandeville C. W., Carey S., Sigurdsson, H., 1996: Sedimentology of the Krakatau 1883 submarine pyroclastic deposits, Bull. Volcanol., vol 57, pp 512.

8. McPhie J., Doyle M., Allen R., 1993: Volcanic textures - A guide to the interpretation of textures in volcanic rocks, Centre for Ore Deposits and Exploration Studies, Univ. of Tasmania, Australia.

9. Morar O., Halga S., Edelstein O., Iştvan D., Bernad A., Vârşescu I., Crihan M., Grancea L., Jurje Z., Kovacs M., Fülöp A., Micle R., Czigler N., 1991: Raport asupra prospectiunilor geologice efectuate în perimetrul Wilhelm - Ulmoasa Băița Nord în anul 1991, Arh. IPEG Maramureş.

10. Nichols G., 1999: Sedimentology \& Stratigraphy, Blackwell Science, 355 pp.

11. Pécskay, Z., Edelstein, O., Kovacs, M., Bernad, A., Crihan, M., 1994: K-Ar age determination of Neogene volcanic rocks from the Gutâi Mts. (Eastern Carpathians, România) Geologica Carpathica, 45, 6, 357-363.

12. Pécskay Z., Edelstein O., Seghedi I., Szakács A., Kovacs M., Crihan M., Bernad A., 1995b: K-Ar datings of Neogene-Quaternary calc-alkaline volcanic rocks in Romania. Acta Vulcanologica, 7,53-62.

13. Pemberton S. G., MacEachern J. A., Frey R. W., 1992: Trace fossils facies models: environmental and allostratigraphic significance in: Facies models response to sea level change, edited by Walker R. G. and James N. P., Geological Association of Canada

14. Rădulescu S., Nedelcu I., Edelstein O., Chițimuş V., Popescu C., Schill E., Bălaşa E., Roşu M., Costache C., Pop E., Stoicescu Gh., 1970: Raport geologic de sinteză cu rezultatele lucrărilor de prospecțiuni din regiunea Baia Mare în perioada 1959-1969, Arh IPEG Maramureş. 
TUFFACEOUS CONGLOMERATES: SYN-ERUPTIVE RESEDIMENTED DEBRIS FLOW

\section{Plate 1}

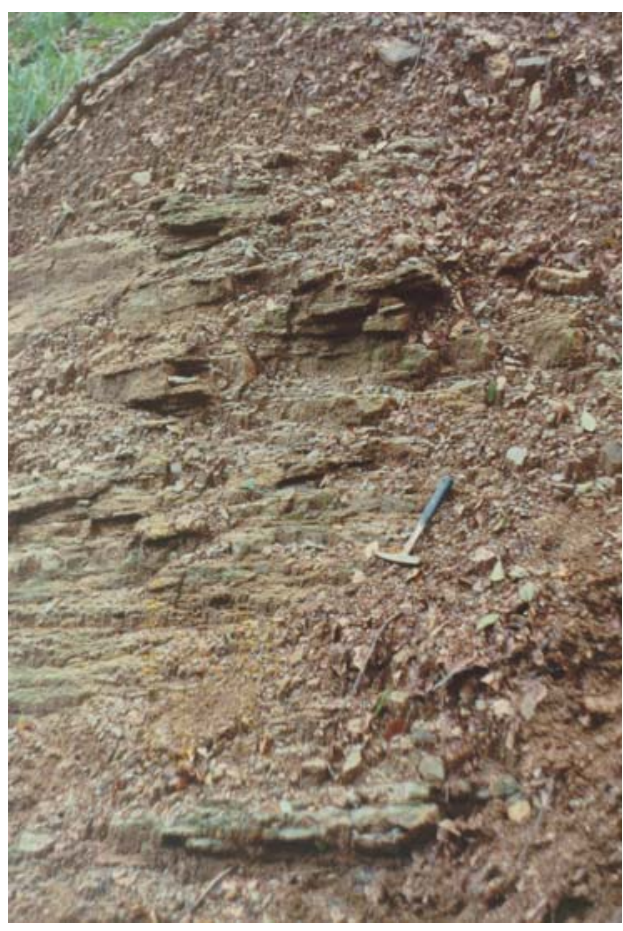

Fig. 1. Photo of the pumice rich layer from outcrop (1), Ulmoasa valley

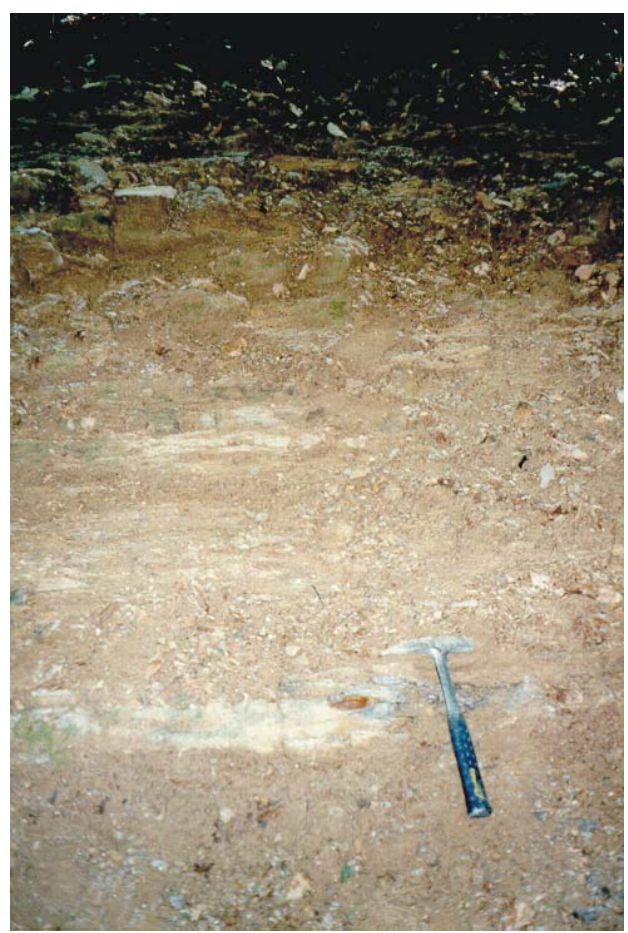

Fig. 2. Photo of the pumice rich layer from outcrops (2), Limpedea valley tributary 


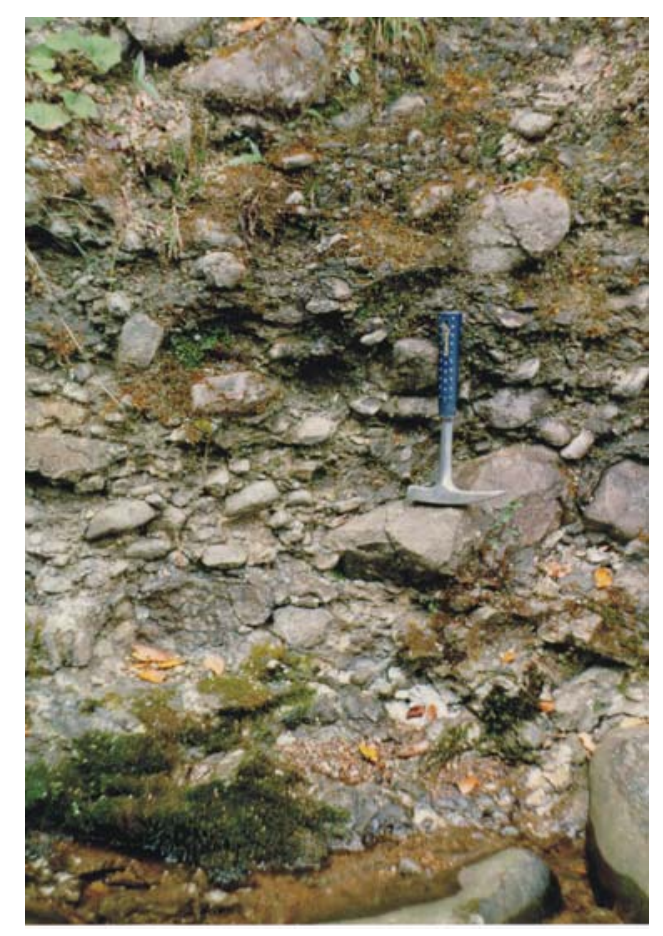

Fig. 3. Photo of the tuffaceous conglomerates from outcrop (1), Ulmoasa valley

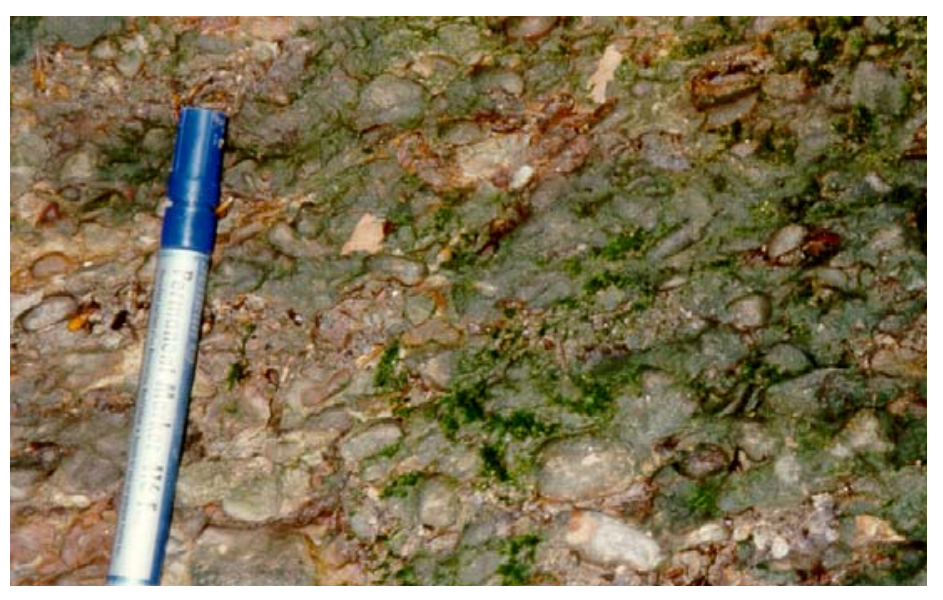

Fig. 4. Photo of the tuffaceous conglomerates from outcrop (2), Limpedea valley tributary 


\section{Plate 2}

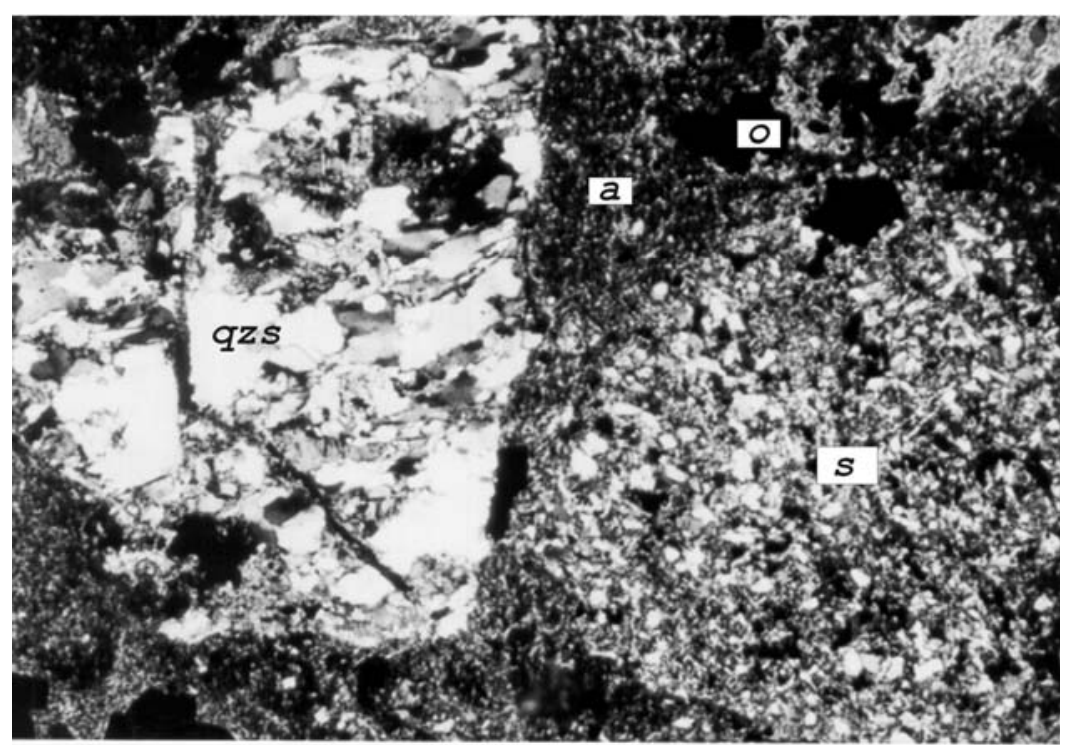

Fig. 1. Microphoto: quartz schist clast (qzs), fine sandstone clast (s), argillized ash (a), opaque minerals (o) in outcrop (3), Limpedea valley; $\mathrm{N+}, 30 \mathrm{X}$

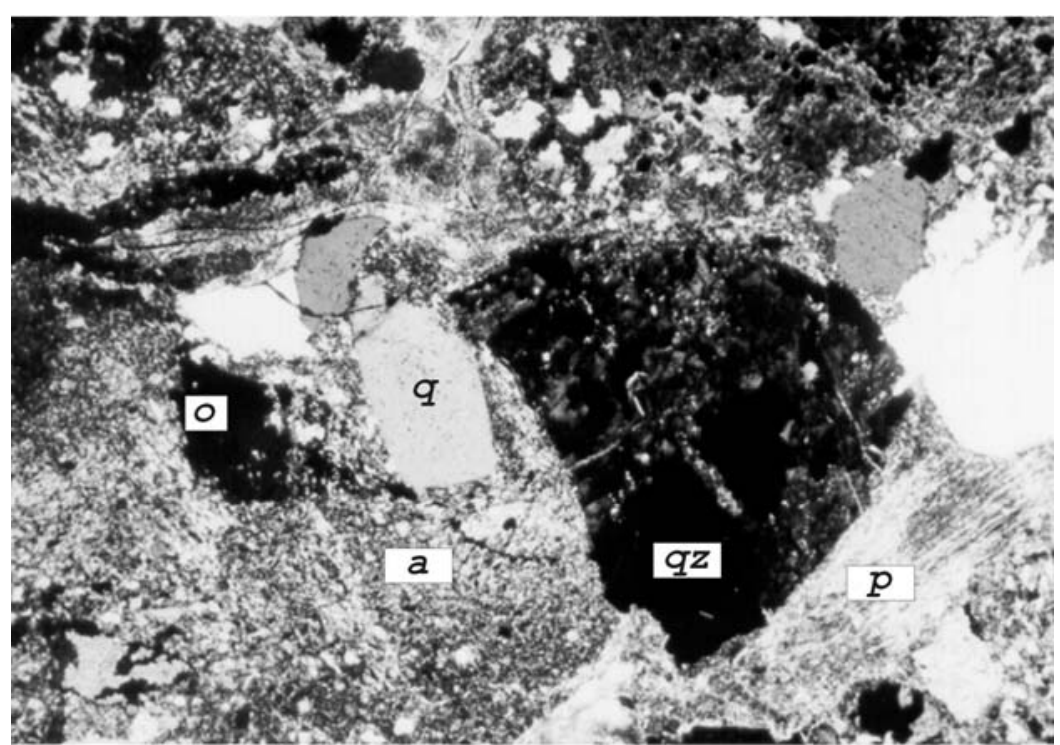

Fig. 2. Microphoto: quartzite clast (qz), quartz phenocryst (q), argillized pumice clasts (p), argillized ash (a), opaque minerals (o) in outcrop (3), Limpedea valley; $N+, 30 X$ 


\section{Plate 3}

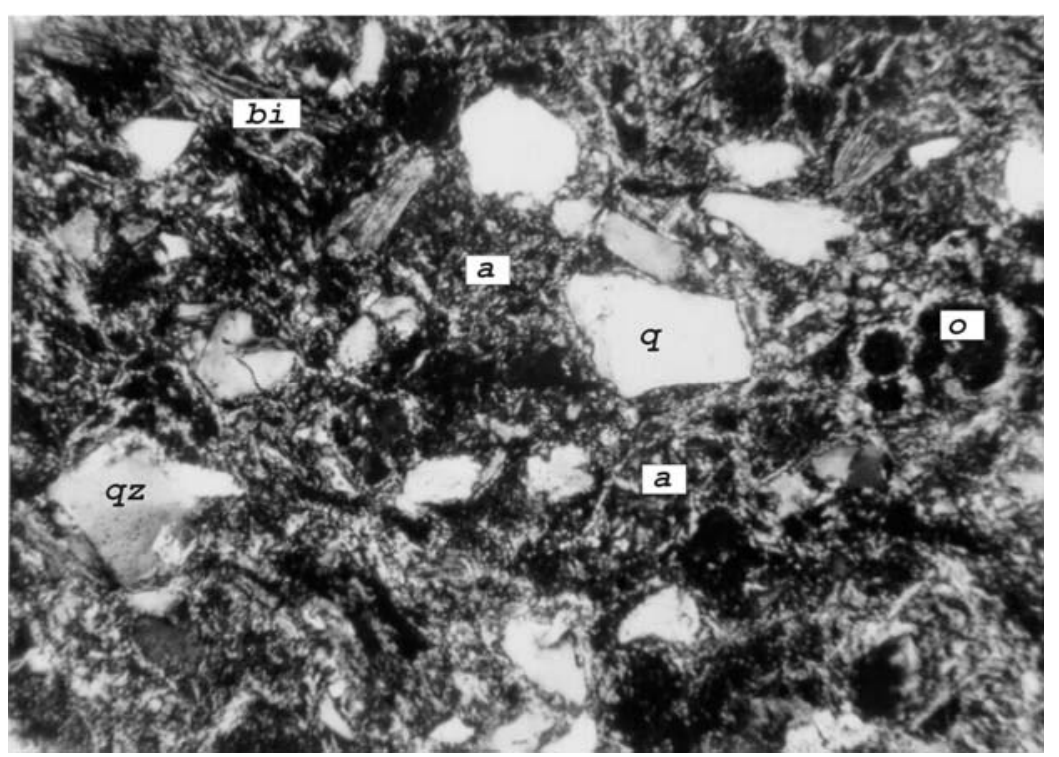

Fig. 1. microphoto: quartz (q), argillized biotite (bi), silicified and argilized ash (a), quartzite clast (qz), opaque minerals (o) in outcrop (3), Limpedea valley; $N+, 60 X$

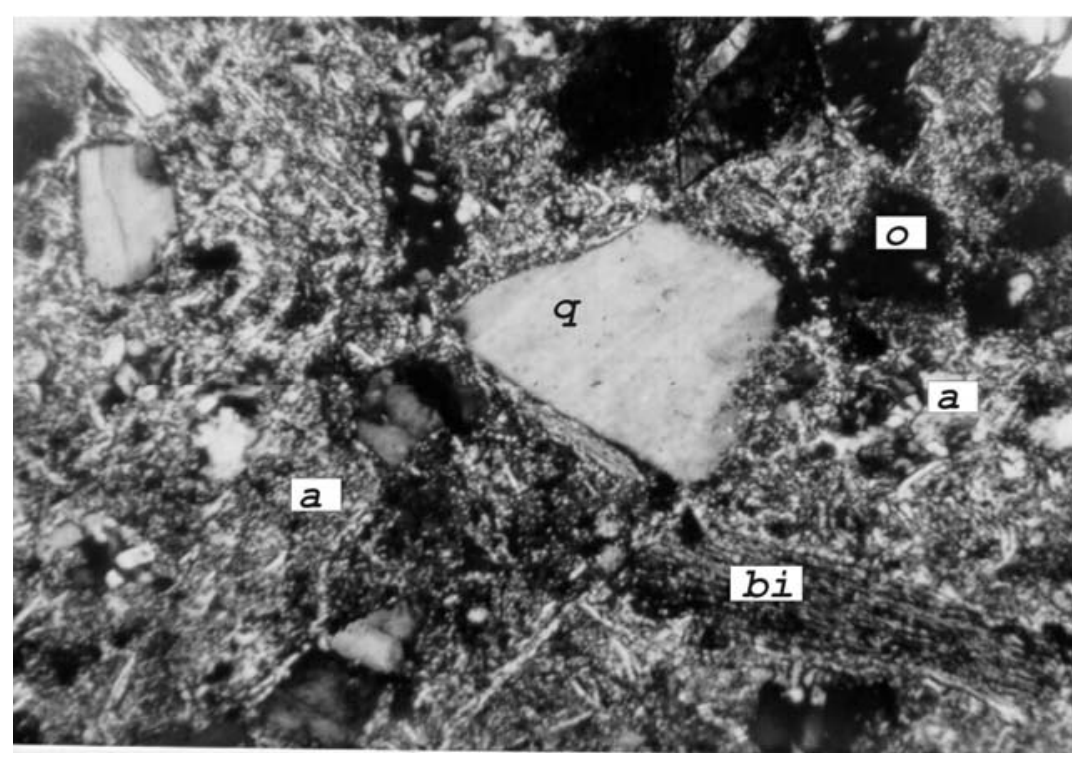

Fig. 2. Microphoto: quartz (q), biotite (bi), argillized and silicified ash (a), opaque minerals (o) in outcrop (3), Limpedea valley; $\mathrm{N+}, 60 \mathrm{X}$ 